Article

\title{
An Alternative Approach to Cataract Surgery Using BSS Temperature of $2.7^{\circ} \mathrm{C}$
}

\author{
Alessandro Meduri ${ }^{1}$, Pasquale Aragona ${ }^{1} \mathbb{D}$, Barbara Testagrossa ${ }^{1}$, Sergio Scolaro ${ }^{1,2}$, \\ Sergio Gurgone $^{3}$, Lilla Bonanno ${ }^{4}$ (D), Francesco Caridi ${ }^{5,6, * \mathbb{D}}$ and Giuseppe Acri ${ }^{1}$ (D) \\ 1 Biomorf Department, University of Messina, 98126 Messina, Italy; alessandro.meduri@unime.it (A.M.); \\ paragona@unime.it (P.A.); barbara.testagrossa@unime.it (B.T.); srgscolaro@gmail.com (S.S.); \\ gacri@unime.it (G.A.) \\ 2 Diapartimento di Patologia umana e dell'età evolutiva “Gaetano Barresi”, University of Messina, \\ 98126 Messina, Italy \\ 3 MIFT Department, University of Messina, 98124 Messina, Italy; sergio.gurgone@unime.it \\ 4 IRCCS, Neurolesi Center, 98125 Messina, Italy; lilla.bonanno@irccsme.it \\ 5 Department of Reggio Calabria, EnvironmentalProtection Agency of Calabria, Italy (ARPACal), \\ Via Troncovito SNC, 89135 Reggio Calabria, Italy \\ 6 Department of Veterinary Sciences, University of Messina, Polo Annunziata, 98166 Messina, Italy \\ * Correspondence: f.caridi@arpacal.it; Tel./Fax: +39-0965372618
}

Received: 28 January 2020; Accepted: 8 April 2020; Published: 13 April 2020

check for updates

\begin{abstract}
The aim of this study is to evaluate the difference in the number of endothelial cells after cataract operations with phacoemulsification by using a balanced salt solution (BSS) at standard temperature (about $20^{\circ} \mathrm{C}$ ) and at $2.7^{\circ} \mathrm{C}$. Two groups, comprising 214 individuals in total, participated in this study; patients were operated on using BSS bottle at about $20^{\circ} \mathrm{C}$ and $2.7^{\circ} \mathrm{C}$ in the first and second groups, respectively. All operations were conducted by the same surgeon and in similar conditions. One month after the operations, endothelial cells in the two groups were checked. For patients in Group 2, an important reduction in the loss of endothelial cells was observed.
\end{abstract}

Keywords: cataract surgery; phacoemulsification; balanced salt solution; endothelial cells

\section{Introduction}

Today, cataracts are globally considered to be a significant factor in the development of blindness, and are a concern from a public health perspective [1]. Cataract surgery-despite being nowadays much more standardized and safe, and widely regarded as an ordinary practice in the ophthalmological field—still has some limitations [2]. Indeed, cataract surgery may present possible postoperative complications such as corneal decompensation [3], the possibility of a cornea with more swelling [4], anterior chamber reaction [5], cystoid macular edema [6], increased intraocular pressure, and, rarely, endophthalmitis [7]. An objective approach to preoperative evaluations is required to obtain the best results [8].

Over the years, different methods have been proposed to make cataract surgery easier and safer, but the revolutionary breakthrough in this area occurred with the development of phacoemulsification. With the use of this technique, it has been possible to achieve a good standard of low-risk efficacy compared to the techniques previously used [9]. The advent of Femto Laser-Assisted Cataract Surgery (FLACS) has indeed decreased the use of ultrasonic energy in the anterior chamber. However, this is primarily due to the laser performing nuclear fragmentation and capsulorhexis, which reduces the level of energy required for nuclear fragmentation and decreases the average loss of endothelial cells to around 20\% [6]. Surgical damage to the endothelium can have severe consequences on functional outcome and on the consequent recovery of the patient [7]. For this reason, for many years, 
technological research has been devoted to reducing this loss, for example by using fewer ultrasounds, thanks to femtosecond lasers [10-13]. Joussen et al. [14] used a cold irrigation temperature solution during phacoemulsification. In this study, the saline bottle was cooled in a refrigerator to $8{ }^{\circ} \mathrm{C}$ and then maintained at room temperature in the operating room.

The aim of this study is to test whether lowering the temperature of the balanced salt solution (BSS) from room average temperature to $2.7^{\circ} \mathrm{C} \pm 0.1^{\circ} \mathrm{C}$ (i.e., the average temperature at the tip of the phacoemulsifier handpiece), and consequently, lowering the temperature in the anterior chamber, has a protective effect on the cells of the endothelial epithelium, and whether this could prevent damage to the corneal endothelium cells during phacoemulsification. The temperature of $2.7^{\circ} \mathrm{C}$, measured at the tip of the phacoemulsifier handpiece, results from a BSS bottle kept inside a thermal "coat" of water and ice, and is a consequence of the experimental setup.

Before performing the study on patients, measurements were conducted using an artificial eye model, manufactured from lactic acid (PLA). In this manner, two objectives were reached: a) correct and reproducible temperature evaluations were achieved; b) patient safety was ensured.

\section{Materials and Methods}

All subjects gave their informed consent for inclusion before they participated in the study. The study was performed according to the ethical principles set in the Declaration of Helsinki [15], and the protocol was approved by the Ethics Committee of Messina, Italy (Project identification code 43/19). The study was conceived and developed in two steps: a preclinical one, simulated on experimental models, and a clinical one, conducted on 214 patients.

In the first step, tests were conducted on an artificial eye model, made of PLA using a 1:1 scale 3D printer [16] and designed for the evaluation of the temperature variation (detected by an immersion probe) near the tip of the phacoemulsifier under different conditions. A thermometer with an immersion probe (WTW $\mathrm{pH} 315 \mathrm{i}$ ), an operating range between $-5.0^{\circ} \mathrm{C}$ and $+105.0^{\circ} \mathrm{C}$, and a resolution of $0.1{ }^{\circ} \mathrm{C}$, was employed for in this phase [17].

Tests were carried out in the operating room (its temperature and humidity were recorded). The temperature of the BSS employed during the simulation of the intervention (for a representative time of $15 \mathrm{~min}$ ) was monitored in two specific conditions:

1. Bottle kept in the operating room for at least three hours

2. Bottle kept in a thermal "coat" made of water and ice.

In the second step, the effects of different temperatures during cataract phacoemulsification were investigated. Two hundred and fourteen patients of both sexes, in apparent good health, were enrolled from among patients that had to undergo cataract surgery from the central vitreous cavity, aged from 55 to 75 years (mean age $69 \pm 8.3$ years, $\mathrm{M}: \mathrm{F}=130: 84$ ). Each patient was classified using an internal protocol, i.e., the degree of the cataract according to the Lens Opacities Classification System III (LOCSIII) [18]. Table 1 reports the degrees of the cataracts included in the study, for each feature proposed in [18] Patients with degree 3 or higher cataracts were included in the study.

Table 1. Cataract grade of patients, according to Lens Opacities Classification System (LOCSIII) classification, included in the study. All treated cataracts were cortical/nuclear, as it is difficult to provide a clear distinction between them.

\begin{tabular}{ccc}
\hline LOCS III Classification & Grade of Opacities & \% of Patients \\
\hline Nuclear Opalescence (NO) and Nuclear Color (NC) & $\geq 3$ & $75 \%$ \\
\hline Cortical Cataract (C) & $\geq 3$ & $20 \%$ \\
\hline Posterior Subcapsular Cataract (P) & $\geq 3$ & $5 \%$ \\
\hline
\end{tabular}

The exclusion criteria from the study were proliferative diabetic retinopathy, previous corneal diseases or any ocular surgical procedures, glaucoma, infections, autoimmune diseases, and malignant 
neoplasias. All patients were pretreated three days prior to the cataract surgery with $1 \%$ sodium hypochlorite $2 \mathrm{X}$ /day to deteriorate periorbital skin, $0.3 \%$ ofloxacin $1 \mathrm{gtt}$ (abbreviation from the Latin "guttae") 3X/day, and bromfenac $(0.9 \mathrm{mg} / \mathrm{mL}) 1 \mathrm{gtt} 2 \mathrm{X} /$ day. Patients were treated using a stable mydriasis

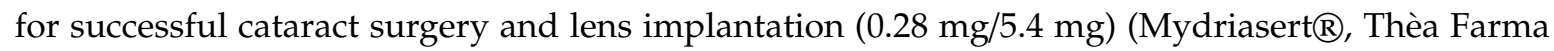
S.p.A., Milan, Italy). The 214 patients were randomly divided into two groups. Group A comprised 110 patients treated with BSS at room temperature in the operating room (i.e., about $20^{\circ} \mathrm{C}$ ). Group B comprised 104 patients treated with BSS at $2.7^{\circ} \mathrm{C}$.

To standardize the two groups, clinical and demographic variables were chosen. In Table 2, the demographic data and the preoperative status lens of the two groups are reported.

Table 2. Table of demographic data and preoperative status of the two groups.

\begin{tabular}{ccc}
\hline & Group A & Group B \\
\hline Number of patients & 110 & 104 \\
\hline Males & 67 & 63 \\
\hline Females & 43 & 41 \\
\hline Mean age & $70 \pm 8.5$ & $68 \pm 8.2$ \\
\hline OD & 58 & 48 \\
\hline OS & 52 & 54 \\
\hline Preoperative status lens & & \\
Phakic & 88 & 87 \\
Pseudophakic & 22 & 17 \\
\hline
\end{tabular}

The use of the thermal "coat" of ice and water ensured that there was no temperature variation during the surgery.

All cataract surgeries were carried out with different intensity setups on the basis of the cataract degree by a surgeon with 10 years of experience, using a traditional OPMI Lumera 700 microscope (Carl Zeiss Vision Italia, S.p.A., Varese, Italy) and a SIGNATURE phacoemulsifier (Johnson \& Johnson Vision Medical SpA, Pomezia-Roma, Italy) [19]; only the initial temperature at the handpiece was considered.

The surgical technique was performed following the routine steps: anesthesia, prepping, draping, setting up the microscope, making an incision, capsulorhexis, nuclear disassembly, cortical cleanup, implantation of the Intra Ocular Lens, and closure of the incision. During Phaco activation, the following parameters were used: flow $25 \mathrm{~mL} / \mathrm{min}$, vacuum 350 and ultrasound energy $30 \%$ (J) (the latter parameters was variable on the basis of the cataract hardness). Each surgery was conducted in a single blind manner. The patient did not know into which group she/he had been assigned. Three checks were performed: preoperatively, one week postoperatively, and thirty days postoperatively. During the preoperative inspection, the patient's suitability for the surgical intervention and inclusion in the study after consent were assessed. The degree of cataract hardness was evaluated through a slit-lamp biomicroscopy examination [20]. Thirty days after surgery, a biomicroscopic check and an assessment of the number of endothelial cells were carried out [21].

To analyze the experimental results, a statistical analysis was performed by a medical physicist (12 years of experience; this person developed the thermal "coat") and a mathematician (10 years of experience) using the open source R3.0 software package [22]. A 95\% of confidence level was set with a $5 \%$ alpha error. Statistical significance was set at $p<0.05$. In particular, the Student's paired t-test was used to compare the pre- and post- treatment results (by intragroups analysis) for each group (A and B). The Student's unpaired t-test was employed for intergroup analysis, specifically, to compare the preand post- treatment results of the two groups. Moreover, an interaction effect analysis was performed by calculating the temperature differences in endothelial cells $\left(\mathrm{T}_{0}-\mathrm{T}_{1}\right)$ and the average amount of ultrasound used (AVG) scores, in order to determine their correlations using the Pearson correlation coefficient in each group. Subsequently, each group (A and B) was divided into four subgroups based 
on the different AVG ranges $(0-9 ; 10-19 ; 20-29 ;>30)$. This range was set according to cataract hardness. One-way ANOVA, followed by a Tukey's post hoc test, was applied to determine possible differences between the four subgroups. The Student's paired and unpaired t-tests were used for each the AVG range of groups A and B for intra- and inter- group analyses, respectively. In addition, the differences between pre- and post- treatment endothelial cells for groups A and B, and for each AVG range, were analyzed using one-way ANOVA and the Student's unpaired t-test.

\section{Results and Discussion}

Preclinical phase data showed that over a time of about $20 \mathrm{~min}$, the temperature inside the bottle both the BSS at $18.0 \pm 0.1^{\circ} \mathrm{C}$ and of the BSS at $2.7 \pm 0.1^{\circ} \mathrm{C}$ did not change when kept at room temperature or at constant cold temperature using the thermal "coat", respectively. Table 3 reports the temperature of the saline solution detected at the outlet of the phacoemulsifier handpiece in the absence of ultrasound (US), under conditions 1 and 2.

Table 3. The temperature of the saline solution detected at the outlet of the phacoemulsifier handpiece in the absence of ultrasound (US), under conditions 1 and 2.

\begin{tabular}{cccc}
\hline Surgery Condition & $\begin{array}{c}\text { Solution Temperature } \\
\text { in the Bottle }\left({ }^{\circ} \mathbf{C}\right)\end{array}$ & $\begin{array}{c}\text { Temperature Output from the } \\
\text { Handpiece }\left({ }^{\circ} \mathbf{C}\right)\end{array}$ & Time \\
\hline 1 & $18.0 \pm 0.1$ & $19.0 \pm 0.1$ & $4 \mathrm{~min}$ \\
\hline 2 & $2.7 \pm 0.1$ & $7.4 \pm 0.1$ & $4 \mathrm{~min}$ \\
\hline
\end{tabular}

When the surgery was simulated using the eye model with US for about one minute (twenty seconds at the maximum power of $80 \mathrm{~mW}$ and forty seconds at a power of $25 \mathrm{~mW}$ ), the saline solution temperature increased and its increments were recorded. In particular, the average temperature variation was $+2.5^{\circ} \mathrm{C}$ (from $19{ }^{\circ} \mathrm{C}$ to $21.5^{\circ} \mathrm{C}$ ) and $+0.4{ }^{\circ} \mathrm{C}$ (from $7.4{ }^{\circ} \mathrm{C}$ to $7.8^{\circ} \mathrm{C}$ ) for conditions 1 and 2, respectively; the maximum temperature variation was $+3.1^{\circ} \mathrm{C}$ (from $19^{\circ} \mathrm{C}$ to $22.1^{\circ} \mathrm{C}$ ) and $+1.0^{\circ} \mathrm{C}$ (from $7.4^{\circ} \mathrm{C}$ to $8.4^{\circ} \mathrm{C}$ ) for conditions 1 and 2, respectively. These results are reported in Table 4 .

Table 4. The average and the maximum temperature variation for one minute of simulated intervention under conditions 1 and 2.

\begin{tabular}{ccccc}
\hline Surgery Condition & $\begin{array}{c}\text { Average Temperature Variation } \\
\left({ }^{\circ} \mathrm{C}\right) \text { over the Time }\end{array}$ & $\begin{array}{c}\text { Maximum Temperature } \\
\text { Variation }\left({ }^{\circ} \mathrm{C}\right) \text { over the Time }\end{array}$ & Time \\
\hline 1 & $+2.5\left(\right.$ from $19^{\circ} \mathrm{C}$ to $\left.21.5^{\circ} \mathrm{C}\right)$ & $+3.1\left(\right.$ from $19^{\circ} \mathrm{C}$ to $\left.22.1^{\circ} \mathrm{C}\right)$ & $1 \mathrm{~min}$ \\
\hline 2 & $+0.4\left(\right.$ from $7.4{ }^{\circ} \mathrm{C}$ to $\left.7.8^{\circ} \mathrm{C}\right)$ & $+1.0\left(\right.$ from $7.8^{\circ} \mathrm{C}$ to $\left.8.4^{\circ} \mathrm{C}\right)$ & $1 \mathrm{~min}$ \\
\hline
\end{tabular}

A preclinical study assessed the reproducibility of the cooling parameters during surgery and confirmed that the temperature variation of BSS solution is smaller when ultrasounds are used together with the cold BSS. It was determined that the temperature increases measured in conditions 1 and 2 would not harm the patients; as such the methodology was applied during "in vivo" cataract surgery.

The clinical study compared the effects on corneal endothelial cell density (ECD) with two different BSS solution temperatures, used as irrigating solutions during phacoemulsification. Patients of Group A received BSS solution at $18.0 \pm 0.1{ }^{\circ} \mathrm{C}$, whereas those of Group B received BSS solution at $2.7 \pm 0.1{ }^{\circ} \mathrm{C}$. There were no significant differences in preoperative variables between the two groups, and no surgical complications occurred in any of the patients involved in the study. With regard to ECD, the two groups did not show statistically significant differences in the number of cells per $\mathrm{mm}^{2}(p=0.12)$ before surgery (Figure 1a), whereas the difference was evident comparing ECD data after surgery (Figure 1b). However, intragroup analyses showed a significant decrease between pre- and post- surgery in ECD, both in patients belonging to Group A $(p<0.001)$ and Group B $(p<0.001)$ (Figure 1). Intergroup analyses revealed that in Group B, ECD was significantly higher than in Group A $(p<0.001)$ (Figure 1). 
These data show that the intraoperative use of a cold eye irrigation solution reduces the loss of corneal number cells. This protection was observed among almost half of the cells.
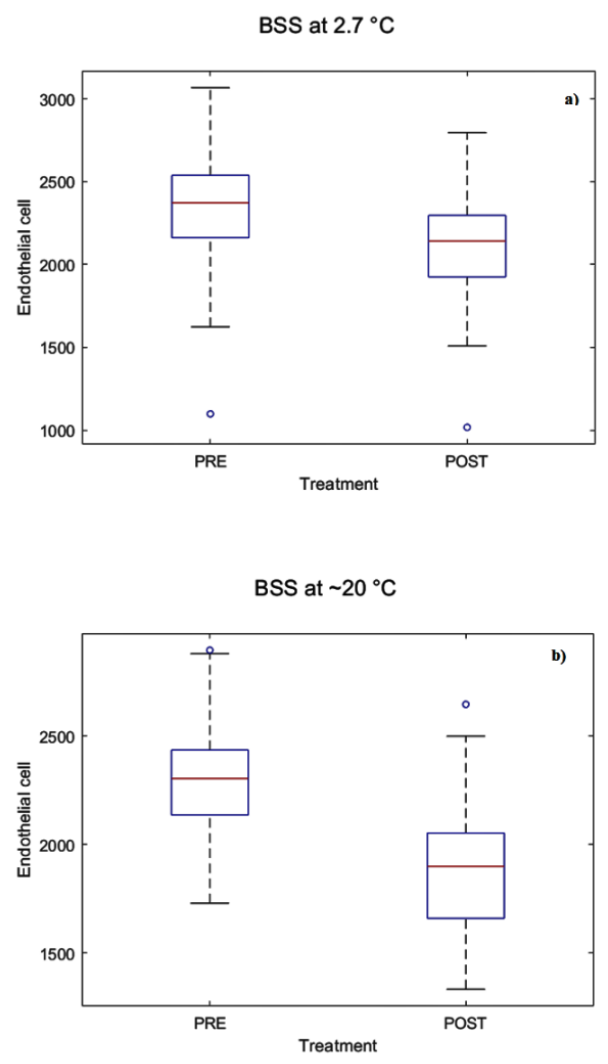

Figure 1. The distribution of endothelial cells with balanced salt solution (BSS) at $2.7^{\circ} \mathrm{C}$ (a) and at $\sim 20^{\circ} \mathrm{C}(\mathbf{b})$, pre- and post- treatment.

Because in each group patients were treated with different protocols of phacoemulsification depending on the cataract degree, we further analyzed the patients of each group by evaluating the impact of phacoemulsification power on postsurgery endothelial health. A significant direct correlation between the loss of endothelial cell density from pre- to post- surgery and different amounts of phacoemulsification ultrasound energy used were observed.

Figure 2 shows the correlation of endothelial cells and AVG, while Figure 3 shows the distribution of endothelial cell differences for BSS at $2.7^{\circ} \mathrm{C}$ and at $\sim 20^{\circ} \mathrm{C}$ between pre- and post- treatment. Intragroup analyses highlighted a significant difference between pre- and post- treatment for the groups A and B $(p<0.001)$ (Table 5$)$ and between the differences of the two groups (Table 4$)$, and a significant negative correlation between endothelial cells and AVG.

Table 5. Intra- and inter- group statistical differences in endothelial cells for the groups A and B (preand post- treatment) and in endothelial cells differences (pre- minus post- treatment).

\begin{tabular}{cccc}
\hline Treatment & $\begin{array}{c}\text { Endothelial Cells at } \mathbf{2 . 7}{ }^{\circ} \mathbf{C} \\
\text { Mean } \pm \text { SD }\end{array}$ & $\begin{array}{c}\text { Endothelial Cells at } \sim \text { 20 } \\
\text { Mean } \pm \text { SD }\end{array}$ & $\begin{array}{c}p \text {-Value } \\
\text { (Student's Unpaired t-Test) }\end{array}$ \\
\hline PRE & $2354 \pm 308.93$ & $2295 \pm 234.46$ & 0.12 \\
\hline POST & $2113 \pm 283.61$ & $1877 \pm 276.54$ & $<0.001{ }^{\S}$ \\
\hline $\begin{array}{c}p \text {-value } \\
(\text { Student's paired t-test) }\end{array}$ & $<0.001 \S$ & $<0.001 \S$ & \\
\hline Differences & $240.87 \pm 73.09$ & $418.63 \pm 185.79$ & $<0.001{ }^{\S}$ \\
\hline \multicolumn{3}{c}{$\S_{p<0.001 .}$}
\end{tabular}




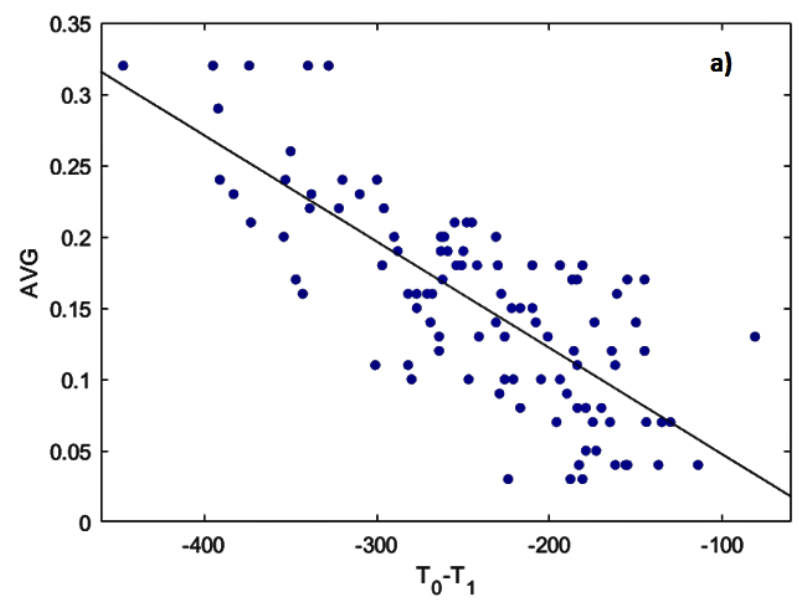

$\sim 20^{\circ} \mathrm{C}$

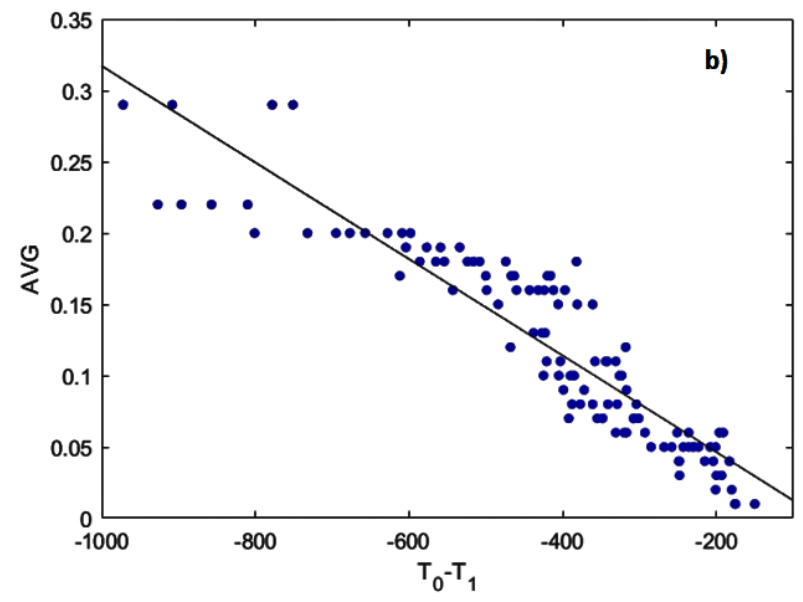

Figure 2. The correlation between endothelial cells (mean difference pre- vs. post- interventions) and the average amount of ultrasound used (AVG) at: (a) BSS at $2.7^{\circ} \mathrm{C}$ and (b) BSS $\sim 2{ }^{\circ} \mathrm{C}$.

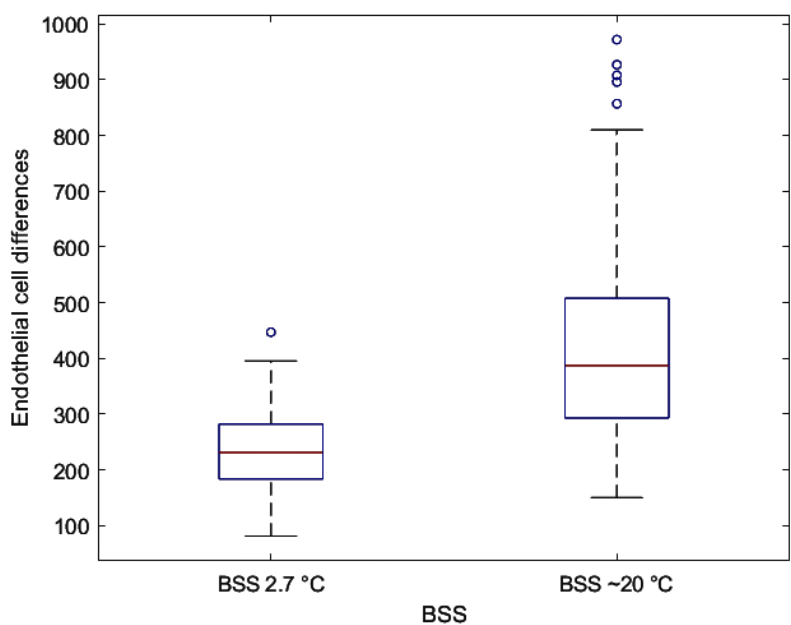

Figure 3. The distribution of endothelial cell differences between pre- and post- treatment with BSS at $2.7^{\circ} \mathrm{C}$ and at $\sim 20^{\circ} \mathrm{C}$. 
In Figure 4, the percentage difference of loss cells and the corresponding error during surgery conditions 1 and 2 are depicted. This figure highlights that the use of BSS at $2.7^{\circ} \mathrm{C}$ reduces the loss of endothelial cells by $50 \%$.

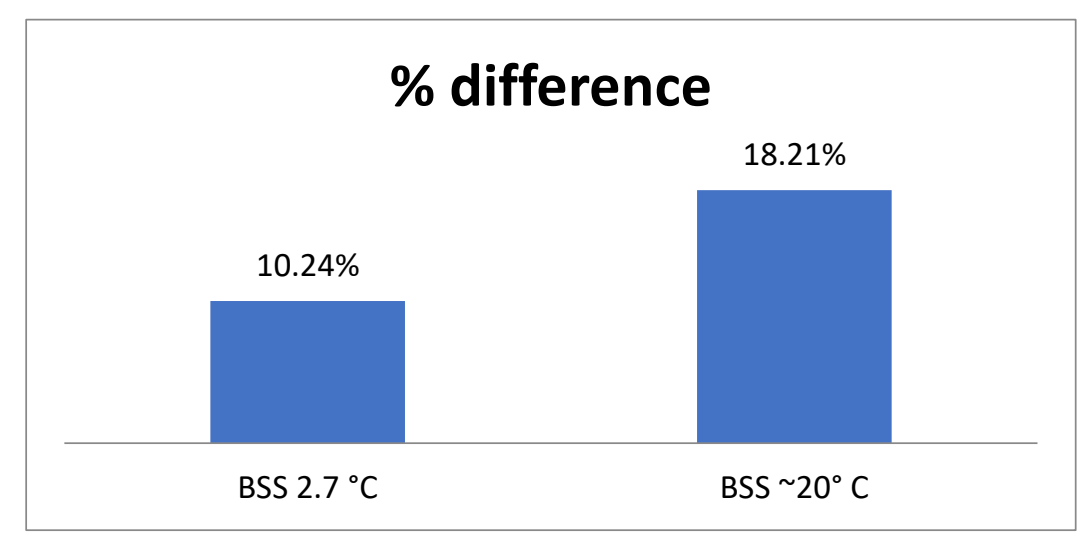

Figure 4. Percentage differences in loss endothelial cells using BSS at $2.7^{\circ} \mathrm{C}$ (Group B) and at $20{ }^{\circ} \mathrm{C}$ (Group A), pre- and post- treatment.

One-way ANOVA (Table 6) put in evidence the significant variation in the AVG post- treatment range in group A $(p<0.001)$. In particular, there was a substantial difference between the $0-9$ and 10-19 AVG range $(p<0.001)$, the 0-9 and 20-29 AVG range $(p<0.001)$, and the 10-19 and 20-29 AVG range $(p<0.001)$. Intragroup analyses showed a highly significative difference in each AVG for both groups. An intergroup analysis highlighted a very significative difference in posttreatment in the $10-19$ AVG range $(p<0.0001)$ and in the $20-29$ AVG range $(p<0.0001)$ (Table 7$)$.

Table 6. One-way ANOVA results.

\begin{tabular}{|c|c|c|c|c|c|}
\hline Treatment & AVG & Patients Number & Mean \pm SD & $p$ & \\
\hline \multirow{3}{*}{ PRE } & $0-9$ & 45 & $2316.2 \pm 255.37$ & \multirow{3}{*}{0.7} & \multirow{6}{*}{ Group A $\left(\mathrm{BSS} \sim 20^{\circ} \mathrm{C}\right)$} \\
\hline & $10-19$ & 49 & $2275.45 \pm 221.15$ & & \\
\hline & $20-29$ & 16 & $2297.15 \pm 221.47$ & & \\
\hline \multirow{3}{*}{ POST } & $0-9$ & 45 & $2050.31 \pm 240.56$ & \multirow{3}{*}{$<0.001 \S$} & \\
\hline & $10-19$ & 49 & $1830.79 \pm 210.55$ & & \\
\hline & $20-29$ & 16 & $1528.62 \pm 132.56$ & & \\
\hline \multirow{4}{*}{ PRE } & $0-9$ & 23 & $2312.08 \pm 313.02$ & \multirow{4}{*}{0.58} & \multirow{8}{*}{ Group B (BSS $\left.2.7^{\circ} \mathrm{C}\right)$} \\
\hline & $10-19$ & 53 & $2368.87 \pm 333.57$ & & \\
\hline & $20-29$ & 23 & $2392.35 \pm 261.01$ & & \\
\hline & $>30$ & 5 & $2215.2 \pm 227.77$ & & \\
\hline \multirow{4}{*}{ POST } & $0-9$ & 23 & $2139.65 \pm 290.43$ & \multirow{4}{*}{0.13} & \\
\hline & 10-19 & 53 & $2141.3 \pm 295.09$ & & \\
\hline & $20-29$ & 23 & $2081.96 \pm 242.66$ & & \\
\hline & $>30$ & 5 & $1838.4 \pm 191.84$ & & \\
\hline
\end{tabular}


Table 7. Intra- and inter- group of subgroups divided by AVG range in endothelial cells for groups A (BSS $\sim 2{ }^{\circ} \mathrm{C}$ ) and $\mathrm{B}\left(\mathrm{BSS} 2.7^{\circ} \mathrm{C}\right.$ ) (pre- and post- treatment).

\begin{tabular}{ccccc}
\hline \multirow{2}{*}{ AVG } & Treatment & $\begin{array}{c}\text { Group A } \\
\text { Mean } \pm \text { SD }\end{array}$ & $\begin{array}{c}\text { Group B } \\
\text { Mean } \pm \text { SD }\end{array}$ & $\begin{array}{c}p \text {-Value } \\
\text { (Student's Unpaired t-Test) }\end{array}$ \\
\hline \multirow{2}{*}{$0-9$} & PRE & $2316.2 \pm 255.37$ & $2312.08 \pm 313.02$ & 0.95 \\
\cline { 2 - 5 } & POST & $2050.31 \pm 240.56^{\S}$ & $2139.65 \pm 290.43 \S$ & 0.18 \\
\hline \multirow{2}{*}{$10-19$} & PRE & $2275.45 \pm 221.15$ & $2368.87 \pm 333.57$ & 0.1 \\
\cline { 2 - 5 } & POST & $1830.79 \pm 210.55^{\S}$ & $2141.3 \pm 295.09 \S$ & $<0.001 \S \S$ \\
\hline \multirow{2}{*}{$20-29$} & PRE & $2297.15 \pm 221.47$ & $2392.35 \pm 261.01$ & 0.24 \\
\cline { 2 - 5 } & POST & $1528.62 \pm 132.56^{\S}$ & $2081.96 \pm 242.66 \S$ & $<0.001 \S \S$ \\
\hline \multirow{2}{*}{$>30$} & PRE & - & $2215.2 \pm 227.77$ & - \\
\cline { 2 - 5 } & POST & - & $1838.4 \pm 191.84 \S$ & - \\
\hline
\end{tabular}

$\S p<0.05$ for the Student's paired t-test between PRE and POST. $\$ \S p<0.05$ for the Student's unpaired t-test between $\mathrm{A}$ and $\mathrm{B}$.

One-way ANOVA also put in evidence a significant variation in AVG range in the endothelial cell differences related to the same group. Tukey's test showed a very significant difference in endothelial cell differences between all the AVG ranges for both groups. An intergroup analysis highlighted a very significant difference in endothelial cell differences between the two groups for every AVG range (Table 8).

Table 8. Intra- and inter- group statistical differences in subgroups differences divided by AVG range of endothelial cells for groups A (BSS $\sim 20^{\circ} \mathrm{C}$ ) and B (BSS $2.7^{\circ} \mathrm{C}$ ).

\begin{tabular}{cccc}
\hline AVG & $\begin{array}{c}\text { Group A } \\
\text { Mean } \pm \text { SD }\end{array}$ & $\begin{array}{c}\text { Group B } \\
\text { Mean } \pm \text { SD }\end{array}$ & $\begin{array}{c}p \text {-Value } \\
\text { (Student's Unpaired t-Test) }\end{array}$ \\
\hline $0-9$ & $268.19 \pm 69.14$ & $172.44 \pm 29.22$ & $<0.001 \S$ \\
\hline $10-19$ & $446.17 \pm 79.39$ & $227.57 \pm 52.79$ & $<0.001 \S$ \\
\hline $20-29$ & $768.5 \pm 119.74$ & $310.39 \pm 50.89$ & $<0.001 \S$ \\
\hline$>30$ & - & $376.8 \pm 47.44$ & - \\
\hline $\begin{array}{c}p \text {-value } \\
(\text { ANOVA })\end{array}$ & $<0.001 \S$ & $<0.001 \S$ &
\end{tabular}

\section{Conclusions}

It is well known that the application of ultrasound during phacoemulsification can lead to endothelial cell damage in cataract surgery due to mechanical trauma from sonic waves and thermal injury [23]. In this scenario, our study demonstrated that the use of a cold irrigation solution plays a pivotal role in reducing or even preventing the damage of corneal endothelial cells during phacoemulsification.

A presurgery test conducted on an artificial eye model allowed us to set the parameters to be used during cataract surgery, to ensure that there was no potential risk for the patients.

In the preoperative period, the two groups of patients did not present statistically significant differences in numbers of endothelial cells. In the postoperative period a clear reduction, i.e., $\sim 50 \%$ of endothelial cells in group A with respect to those in group B $(p<0.001)$ was found.

We also evaluated subgroups in relation to the AVG and found that there were no significant differences in the softer cataracts, which required an ultrasound percentage of less than $10 \%$ of the maximum power. Of note is the data showing a greater reduction in subjects in group B with medium 
and hard cataract using ultrasounds higher than $10 \%$, among whom we did not observe large losses of endothelial cells compared to those in group A, despite the high percentage of ultrasound used.

For these reasons, and considering the protective role of BSS at low temperature $\left(2.7 \pm 0.1^{\circ} \mathrm{C}\right)$, we propose the use of this new technique mainly in medium and hard cataracts and in subjects at risk of corneal decompensation.

Despite these encouraging results, further studies are needed to establish the optimal BSS temperature at which the maximum anti-inflammatory effect can be achieved without causing cold damage. The reproducibility and relatively low cost of the method facilitate its widespread use.

Author Contributions: Conceptualization, A.M and G.A.; methodology, A.M., G.A., S.S.; validation, F.C., G.A.; formal analysis, L.B., S.G.; investigation, A.M., P.A., S.S.; resources, A.M., P.A., S.S.; data curation, B.T.; writing—original draft preparation, F.C., G.A.; writing—review and editing, F.C., G.A., S.G.; supervision, P.A.; All authors have read and agreed to the published version of the manuscript.

Funding: This research received no external funding.

Conflicts of Interest: The authors declare no conflict of interest.

\section{References}

1. Thylefors, B. The World Health Organization's programme for the prevention of blindness. Int. Ophthalmol. 1990, 14, 211-219. [CrossRef] [PubMed]

2. Christen, W.G.; Glynn, R.J.; Ajani, U.A. Smoking cessation and risk of age-related cataract in men. JAMA 2000, 284, 713-716. [CrossRef] [PubMed]

3. Doors, M.; Berendschot, T.T.J.M.; Touwslager, W.; Webers, C.A.; Nuijts, R.M.M.A. Phacopower modulation and the risk for postoperative corneal decompensation: A randomized clinical trial. JAMA Ophthalmol. 2013, 131, 1443-1450. [CrossRef] [PubMed]

4. Lundberg, B.; Jonsson, M.; Behndig, A. Postoperative corneal swelling correlates strongly to corneal endothelial cell loss after phacoemulsification cataract surgery. Am. J. Ophthalmol. 2005, 139, 1035-1041. [CrossRef] [PubMed]

5. Shah, S.M.; Spalton, D.J. Changes in anterior chamber flare and cells following cataract surgery. $B r . J$. Ophthalmol. 1994, 78, 91-94. [CrossRef] [PubMed]

6. Gandhi, J.S. Cystoid macular edema after cataract surgery. J. Cataract Refract. Surg. 2018, 44, 1536. [CrossRef] [PubMed]

7. Vieira, I.V.; Boianovsky, C.; Saraiva, T.J.; Godoy, R.B.; de Lake, J. Safety and efficacy of intracameral moxifloxacin injection for prophylaxis of endophthalmitis after phacoemulsification. Arq. Bras. Oftalmol. 2017, 80, 165-167. [CrossRef] [PubMed]

8. Cho, K.; Lim, D.H.; Yang, C.M.; Chung, E.S.; Chung, T.Y. Comparison of Intraocular Lens Power Calculation Methods Following Myopic Laser Refractive Surgery: New Options Using a Rotating Scheimpflug Camera. Korean J. Ophthalmol. 2018, 32, 497-505. [CrossRef] [PubMed]

9. Li, S.; Chen, X.; Zhao, J.; Xu, M.; Yu, Z. Isolated Capsulorhexis Flap Technique in Femtosecond Laser-Assisted Cataract Surgery to Protect the Corneal Endothelial Cells. J. Investig. Surg. 2017, 32, 35-38. [CrossRef] [PubMed]

10. Stănilă, D.M.; Florea, A.M.; Stănilă, A.; Panga, A.A. Endothelial cells loss to the hyperopic pacients during phacoemulsification. Rom. J. Ophthalmol. 2017, 61, 256.

11. Pajic, B.; Cvejic, Z.; Pajic-Eggspuehler, B. Cataract Surgery Performed by High Frequency LDV Z8 Femtosecond Laser: Safety, Efficacy, and Its Physical Properties. Sensors 2017, 17, 1429. [CrossRef] [PubMed]

12. Agarwal, A.; Jacob, S. Current and effective advantages of femtophacoemulsification. Curr. Opin. Ophthalmol. 2017, 28, 49-57. [CrossRef] [PubMed]

13. Kanellopoulos, A.J.; Asimellis, G. Standard manual capsulorhexis/Ultrasound phacoemulsification compared to femtosecond laser-assisted capsulorhexis and lens fragmentation in clear cornea small incision cataract surgery. Eye Vis. 2016, 3, 20. [CrossRef] [PubMed]

14. Joussen, A.M.; Barth, U.; Çubuk, H.; Koch, H.R. Effect of irrigating solution and irrigation temperature on the cornea and pupil during phacoemulsification. J. Cataract Refract. Surg. 2000, 26, 392-397. [CrossRef] 
15. World Medical Association. Declaration of Helsinki: Ethical Principles for Medical Research Involving Human Subjects. JAMA 2013, 310, 2191-2194. [CrossRef] [PubMed]

16. R2Evo 3DMarkerLab. Available online: http://www.3dmarketlab.it (accessed on 20 January 2020).

17. Handheld Meter pH315i Operating Manual. Available online: http://www.globalw.com/downloads/WQ/ PH3150i.pdf (accessed on 20 January 2020).

18. Chylack, L.T.; Wolfe, J.K.; Singer, D.M.; Leske, M.C.; Bullimore, M.A.; Bailey, I.L.; Friend, J.; McCarthy, D.; $\mathrm{Wu}, \mathrm{S}$. The Lens Opacities Classification System III-Longitudinal Study of cataract study Group. Arch. Ophtalmol. 1993, 111, 831-836. [CrossRef] [PubMed]

19. Whitestar Signature PRO-Johnson \& Johnson Vision. Available online: https://www.dc-ophthalmology. com/products/193 (accessed on 20 January 2020).

20. SL990-Series Slitlamps Operating Manual. Available online: http://www.iproweb.fr/test/0\%20-\%20MATOS\% 20GUILLAUME/CSO\%20-\%20SL990\%20TYPE\%205X\%20D\%20LAMPE\%20A\%20FENTE/SL990.pdf (accessed on 20 January 2020).

21. Takahashi, H. Corneal Endothelium and Phacoemulsification. Cornea 2016, 35, S3-S7. [CrossRef] [PubMed]

22. R Software Open Source. Available online: https://rextester.com/l/r_online_compiler (accessed on 8 January 2020).

23. Walkow, T.; Anders, N.; Klebe, S. Endothelial cell loss after phacoemulsification: Relation to preoperative and intraoperative parameters. J. Cataract Refract. Surg. 2000, 26, 727-732. [CrossRef]

(C) 2020 by the authors. Licensee MDPI, Basel, Switzerland. This article is an open access article distributed under the terms and conditions of the Creative Commons Attribution (CC BY) license (http://creativecommons.org/licenses/by/4.0/). 